\title{
Compensatory elevation of complex II activity in Leber's hereditary optic neuropathy
}

Department of Ophthalmology, Taipei Veterans General Hospital, Taipei, Taiwan, ROC

M-Y Yen

$\mathrm{J}-\mathrm{H}$ Liu

\section{Department of} Biochemistry, National Yang-Ming

University, Taipei,

Taiwan, ROC

H-C Lee

Y-H Wei

Correspondence to: May-Yung Yen, MD, Department of

Ophthalmology, Taipei Veterans General Hospital, National Yang-Ming University, Taipei, 11217 Taiwan, ROC.

Accepted for publication 13 September 1995

\author{
May-Yung Yen, Hsin-Chen Lee, Jorn-Hon Liu, Yau-Huei Wei
}

\begin{abstract}
Aims-To evaluate the mitochondrial respiratory enzyme activities in blood cells of Leber's hereditary optic neuropathy (LHON) with 11778 point mutation of mitochondrial DNA.
\end{abstract}

Methods-Assays for the activities of NADH-cytochrome $c$ reductase (complex I+complex III), succinate-cytochrome $c$ reductase (complex II+complex III), and cytochrome $c$ oxidase (complex IV) on blood cell mitochondria of seven LHON patients and 15 normal controls.

Results-There was no statistically significant difference in NADH-cytochrome $c$ reductase and cytochrome $c$ oxidase activities between LHON patients and controls, but activities of succinatecytochrome $c$ reductase in LHON patients was significantly elevated compared with normal controls.

Conclusion-The observations that the activity of NADH-cytochrome $c$ reductase is normal but that of succinate-cytochrome c reductase is increased in LHON patients with 11778 point mutation of mitochondrial DNA indicate an elevation of complex II activity, which may be due to a nuclear compensatory effect for defects of the respiratory function of mitochondria.

(Br f Ophthalmol 1996; 80: 78-81)

Leber's hereditary optic neuropathy (LHON) is a maternally inherited disease causing acute or subacute visual loss predominantly in young men. A point mutation at nucleotide position 11778 of mitochondrial DNA (mtDNA) that alters a highly conserved amino acid from arginine to histidine in subunit 4 (ND4) of complex I of the respiratory chain was dis- covered by Wallace and colleagues in patients with LHON. ${ }^{1}$ Several other mutations have since been reported to be associated with LHON. ${ }^{2-13}$ None of them occurs in the same gene affecting ND4, and most such mutations affect other subunits of the same complex in the respiratory chain.

Human mtDNA contains genes coding for 2 rRNA, 22 tRNA, and 13 polypeptides that are involved in mitochondrial respiration and oxidative phosphorylation (OXPHOS) ${ }^{14}$ The OXPHOS system contains five enzyme complexes located in the mitochondrial inner membrane, the biogenesis of which is controlled by both nuclear and mitochondrial genomes. Complexes I, II, III, and IV comprise the chain of electron transport according to which $\mathrm{NADH}$ and succinate become oxidised, respectively, and an electrochemical potential of proton gradient is concurrently generated across the mitochondrial inner membrane. ${ }^{15}$ Complex V utilises this potential energy to condense ADP and inorganic phosphate into ATP (Fig 1). ${ }^{16}$

Among 60 or more polypeptides comprising the OXPHOS system of animal and human cells, 13 are encoded with mtDNA. ${ }^{17}$ These include seven subunits of complex I (NADH-ubiquinone oxidoreductase), one subunit of complex III (ubiquinol-cytochrome $c$ oxidoreductase), three subunits of complex IV (cytochrome $c$ oxidase), and two subunits of complex V (ATP synthase). The remaining subunits of these complexes, including all complex II, are encoded with nuclear DNA.

Since Wallace and colleagues discovered 11778 point mutation in LHON patients, at least 11 transition mutations located in different genes for the mitochondrially encoded subunits of the respiratory chain complexes have

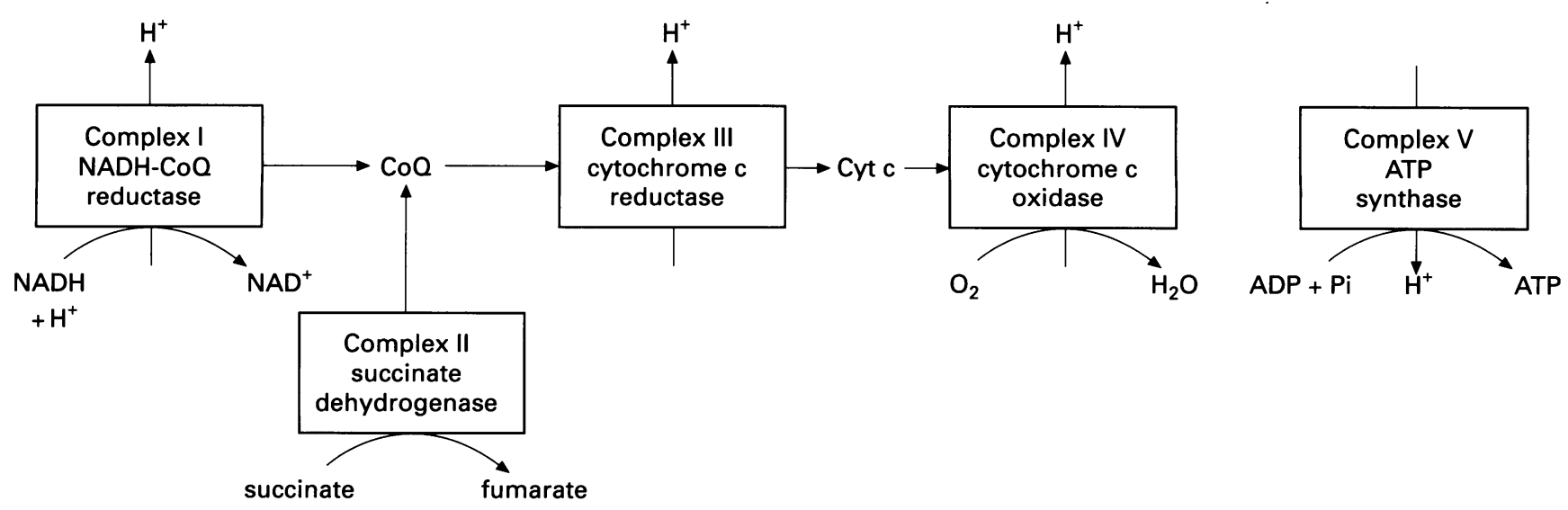

Figure 1 Schematic representation of the major elements of the respiratory chain of the mitochondrion. The enzyme complexes are numbered I-V. $\mathrm{CoQ}=$ coenzyme $Q ;$ Cyt $c=$ cytochrome $c$. 
been associated thus far with this disease. The pathogenesis of LHON remains unknown. Although some enzyme activities had been found reduced in LHON patients with ND1/3460 mutation ${ }^{18}$ and ND1/4160 mutation, ${ }^{19}$ no abnormalities in complex I activity in patients with ND4/11778 mutation have been found. ${ }^{18} 20-22$

The 11778 mutation in the mtDNA of LHON patients affects the ND4 gene of complex I, which may cause defects in functioning of the respiratory chain. It is, therefore, of special interest to examine the mitochondrial respiratory function in LHON patients with 11778 point mutation in mtDNA. We have thus assayed the activities of NADHcytochrome $c$ reductase (complexes I+III), succinate-cytochrome $c$ reductase (complexes II +III), and cytochrome $c$ oxidase (complex IV) of blood cells from patients with 11778 point mutation of $\mathrm{mtDNA}$ and compared them with those of controls.

\section{Materials and methods}

\section{BLOOD SAMPLING}

Seven patients from four families with LHON were examined. Six patients were male and one was female. The age of patients when they received the test was in the range 16-57 years. The vision of patients varied from $20 / 70$ to light perception. Fifteen independent normal subjects of age range $17-50$ years were examined as controls. The distributions of the ages of patients and controls are shown in Tables 1 and 2. Blood samples were obtained with consent from LHON patients and from healthy volunteers. The blood was withdrawn into a glass tube containing heparin. Molecular tests confirmed that all patients had homoplasmic 11778 point mutation in mtDNA of their blood cells as described previously. ${ }^{23}$ They were tested negative for some other point mutations that have been reported $(3460,4216,4917$, $13708,14484,15257$ ) and negative for known polymorphisms.

\section{ISOLATION OF MITOCHONDRIA FROM WHOLE BLOOD}

Whole blood $(10 \mathrm{ml})$ was used to isolate mitochondria according to a method described previously $^{24}$ with modification. The sample was washed with TE buffer $[20 \mathrm{mM}$ Tris- $\mathrm{HCl}, 1$ $\mathrm{mM}$ EDTA (ethylenediaminetetra-acetic acid), $\mathrm{pH}$ 8.0] and then centrifuged for 1 minute at $13000 \times g$. The supernatant was discarded. The pellet was homogenised in a buffer containing $0.25 \mathrm{M}$ sucrose, $0.5 \mathrm{mM}$ EDTA, and $3 \mathrm{mM}$ HEPES, at $\mathrm{pH} 7 \cdot 2$ (SEH buffer). The homogenate was subjected to centrifugation at $800 \times g$ for 10 minutes and the supernatant centrifuged at $10000 \times g$ for 10 minutes. The pellet, enriched with mitochondria, was suspended in a minimal volume of SEH buffer. After freeze thawing, the mitochondrial suspension was used for assay of respiratory enzyme activity.
ASSAY OF ELECTRON TRANSPORT ACTIVITIES The electron transport activities of various respiratory enzyme complexes were determined according to methods described previously. ${ }^{25} 26 \mathrm{NADH}$-cytochrome $c$ reductase activity was measured by following the reduction of exogenous oxidised cytochrome $c$ at $550 \mathrm{~nm}$ with a spectrophotometer after addition of a suitable volume of mitochondrial suspension to the assay mixture. The assay mixture in $1 \mathrm{ml}$ of total volume contained 50 $\mu \mathrm{M}$ cytochrome $c, 1.5 \mathrm{mM} \mathrm{KCN}, 100 \mu \mathrm{M} \beta$ $\mathrm{NADH}$ (freshly prepared), and $50 \mathrm{mM}$ $\mathrm{K}_{2} \mathrm{HPO}_{4}(\mathrm{pH} \mathrm{7 \cdot 4)}$. The reaction was initiated by the addition of 10-20 $\mu \mathrm{l}$ mitochondrial suspension (protein concentration $3-5 \mathrm{mg} / \mathrm{ml}$ ).

The activity of succinate-cytochrome $c$ reductase was assayed by following the reduction of exogenous oxidised cytochrome $c$ at $550 \mathrm{~nm}$ with a spectrophotometer. The assay mixture in $1 \mathrm{ml}$ contained the following: 50 $\mu \mathrm{M}$ cytochrome $c, 1.5 \mathrm{mM} \mathrm{KCN}, 20 \mathrm{mM}$ succinate, and $40 \mathrm{mM} \mathrm{K}_{2} \mathrm{HPO}_{4}(\mathrm{pH} \mathrm{7 \cdot 4})$. An aliquot of 15-20 $\mu \mathrm{l}$ mitochondrial suspension was pre-incubated at $37^{\circ} \mathrm{C}$ for 30 minutes with the assay mixture that contained no cytochrome $c$. Enzyme reaction was initiated on addition of cytochrome $c$ and absorbance increase at $550 \mathrm{~nm}$ was recorded for 3 minutes.

The activity of cytochrome $c$ oxidase was determined by following the oxidation of exogenously reduced cytochrome $c$ at $550 \mathrm{~nm}$ with a spectrophotometer. The assay mixture was pre-incubated at $30^{\circ} \mathrm{C}$ for 30 minutes, and combined with reduced cytochrome $c$ and 10-15 $\mu$ l of mitochondrial suspension. The assay mixture in $1 \mathrm{ml}$ of total volume contained $0.45 \mathrm{mM}$ reduced cytochrome $c$ and 75 $\mathrm{mM} \mathrm{K}_{2} \mathrm{HPO}_{4}(\mathrm{pH} \mathrm{7} \cdot 4)$. The reaction was initiated on addition of mitochondrial suspension (10-20 $\mu \mathrm{l})$.

Reduced cytochrome $c$ was prepared by mixing an aliquot $(5-10 \mathrm{ml})$ of $1 \mathrm{mM}$ oxidised cytochrome $c$ with excess sodium dithionite at $4^{\circ} \mathrm{C}$ for 5 minutes. After reduction, the mixture was applied to a Sephadex G-25 column $\left(1.5 \times 45 \mathrm{~cm}^{2}\right)$ to separate reduced cytochrome $c$ from sodium dithionite. The ratio $A_{550 \mathrm{~nm}} /$ $\mathrm{A}_{565 \mathrm{~nm}}$ of reduced cytochrome $c$ was expected to exceed $6 \cdot 0$. When $A_{550 \mathrm{~nm}}$ equals 0.83 , the concentration of cytochrome $c$ is $0.045 \mathrm{mM}$.

The concentration of protein in the mitochondrial suspension was determined by a modified Lowry method. 27

\section{Results}

Tables 1 and 2 show the activities of electron transport of blood cell mitochondria of all patients and normal controls.

The mean (SD) activities of NADHcytochrome $c$ reductase, succinate-cytochrome $c$ reductase, and cytochrome $c$ oxidase in LHON patients with mtDNA 11778 point mutation were 134.65 (24.09), 38.03 (5.82), and $16 \cdot 11(2 \cdot 86) \mathrm{nmol} / \mathrm{min} / \mathrm{mg}$, respectively. The mean activities of NADH-cytochrome $c$ reductase, succinate-cytochrome $c$ reductase, and cytochrome $c$ oxidase in normal controls were $134.28(58.31), 19.29(8 \cdot 12)$, and 13.83 
Table 1 Activities of the respiratory enzyme complexes in patients with 11778 mutation in $m t D N A$

\begin{tabular}{|c|c|c|c|c|c|c|}
\hline \multirow[b]{2}{*}{ Case } & \multirow[b]{2}{*}{ Age/sex } & \multirow[b]{2}{*}{$V A$} & \multirow{2}{*}{$\begin{array}{l}\text { Age of } \\
\text { onset }\end{array}$} & \multicolumn{3}{|c|}{ Enzyme activity ( $\mathrm{nmol} / \mathrm{min} / \mathrm{mg})$} \\
\hline & & & & Complexes $I+I I$ & Complexes $I I+I I I$ & Complex IV \\
\hline 1 & $32 / \mathrm{M}$ & $\begin{array}{l}20 / 200 \\
20 / 200\end{array}$ & 10 & $147 \cdot 68$ & $37 \cdot 64$ & $12 \cdot 64$ \\
\hline 2 & $57 / F$ & $\begin{array}{l}\mathrm{LP} \\
\mathrm{LP}\end{array}$ & 17 & $168 \cdot 50$ & $48 \cdot 25$ & $17 \cdot 41$ \\
\hline 3 & $29 / \mathrm{M}$ & $\begin{array}{l}\overline{H M} \\
\mathrm{HM}\end{array}$ & 28 & $145 \cdot 64$ & $39 \cdot 95$ & $20 \cdot 63$ \\
\hline 4 & $23 / \mathrm{M}$ & $\begin{array}{l}\mathrm{LP} \\
\mathrm{LP}\end{array}$ & 13 & $126 \cdot 40$ & $41 \cdot 74$ & $18 \cdot 32$ \\
\hline 5 & $16 / \mathrm{M}$ & $\begin{array}{l}\text { CF } \\
\text { CF }\end{array}$ & 16 & $107 \cdot 75$ & 31.90 & $13 \cdot 67$ \\
\hline 6 & $18 / \mathrm{M}$ & $\begin{array}{l}20 / 400 \\
20 / 400\end{array}$ & 15 & $145 \cdot 67$ & $34 \cdot 32$ & $14 \cdot 06$ \\
\hline \multirow[t]{2}{*}{7} & $25 / \mathrm{M}$ & $\begin{array}{l}20 / 70 \\
20 / 50\end{array}$ & 17 & $100 \cdot 97$ & $32 \cdot 58$ & $16 \cdot 08$ \\
\hline & Mean (SD) & & & $134 \cdot 65(24 \cdot 09)$ & $38.03(5 \cdot 82)$ & $16 \cdot 11(2 \cdot 86)$ \\
\hline
\end{tabular}

$\mathrm{VA}=$ visual acuity, $\mathrm{HM}=$ hand movements, $\mathrm{LP}=$ light perception, $\mathrm{CF}=$ counting fingers

(4.63) $\mathrm{nmol} / \mathrm{min} / \mathrm{mg}$, respectively. There was no statistically significant difference of activities of NADH-cytochrome $c$ reductase and cytochrome $c$ oxidase between patients and controls (Mann-Whitney test, $\mathrm{p}>0.05$ ). The mean activites of succinate-cytochrome $c$ reductase in patients significantly exceeded those of controls (Mann-Whitney test, $\mathrm{p}<0 \cdot 05$ ).

\section{Discussion}

Since Wallace and colleagues discovered the 11778 point mutation in LHON patients, at least 11 mutations are reported. ${ }^{2-13}$ Although some such mutations are strongly suggested to be a causative factor of LHON, the energy metabolism and its possible role in pathogenesis remains unknown. Reduced activity of NADH-ubiquinone oxidoreductase of complex I in LHON patients with ND1/4160 mutation is reported by Parker and colleagues. ${ }^{19}$ Reduced activity of NADH-ubiquinone reductase in patients with ND1/3460 mutation is reported by Majander and colleagues. ${ }^{18}$ However, normal complex I activity in muscle mitochondria was reported in patients with ND4/11778 mutation. ${ }^{18}$ 20-22

Majander et al ${ }^{18}$ found that the ND1/3640 mutation causes $80 \%$ reduction of rotenone sensitive and ubiquinone dependent electron transfer activities, whereas the proximal NADH dehydrogenase activity of the complex I is unaffected. They also found that, in patients with $\mathrm{ND} 4 / 11778$ mutation, $\mathrm{Km}$ for

Table 2 Activities of respiratory enzyme complexes in normal controls

\begin{tabular}{|c|c|c|c|c|}
\hline \multirow[b]{2}{*}{ Case } & \multirow[b]{2}{*}{ Age/sex } & \multicolumn{3}{|c|}{ Enzyme activity (nmol/min/mg) } \\
\hline & & Complexes I+II & Complexes $I I+I I I$ & Complex IV \\
\hline \multirow{16}{*}{$\begin{array}{r}1 \\
2 \\
3 \\
4 \\
5 \\
6 \\
7 \\
8 \\
9 \\
10 \\
11 \\
12 \\
13 \\
14 \\
15\end{array}$} & $17 / \mathrm{F}$ & $167 \cdot 96$ & $14 \cdot 48$ & $15 \cdot 35$ \\
\hline & $17 / F$ & 188.92 & $18 \cdot 10$ & $15 \cdot 79$ \\
\hline & $22 / \mathrm{M}$ & $74 \cdot 04$ & $8 \cdot 52$ & $5 \cdot 82$ \\
\hline & $28 / \mathrm{F}$ & $231 \cdot 44$ & $19 \cdot 89$ & $12 \cdot 07$ \\
\hline & $29 / \mathrm{M}$ & $127 \cdot 08$ & 19.53 & $18 \cdot 52$ \\
\hline & $30 / \mathrm{F}$ & $52 \cdot 47$ & $10 \cdot 36$ & $5 \cdot 70$ \\
\hline & $30 / \mathrm{F}$ & 164.09 & $17 \cdot 28$ & 14.55 \\
\hline & $31 / F$ & $182 \cdot 28$ & $17 \cdot 32$ & $17 \cdot 29$ \\
\hline & $32 / \mathrm{M}$ & $98 \cdot 77$ & 19.95 & $10 \cdot 06$ \\
\hline & 35/M & $75 \cdot 62$ & $18 \cdot 73$ & $24 \cdot 13$ \\
\hline & $39 / \mathrm{F}$ & $100 \cdot 46$ & $21 \cdot 09$ & $14 \cdot 05$ \\
\hline & 44/M & $239 \cdot 94$ & $21 \cdot 69$ & $14 \cdot 13$ \\
\hline & $45 / \mathrm{F}$ & $123 \cdot 87$ & $17 \cdot 17$ & 11.79 \\
\hline & 47/M & 98.96 & $20 \cdot 00$ & 14.95 \\
\hline & $50 / F$ & $88 \cdot 35$ & $45 \cdot 37$ & $12 \cdot 89$ \\
\hline & Mean (SD) & $134 \cdot 28(58 \cdot 31)$ & $19 \cdot 29(8 \cdot 12)$ & $13.83(4.63)$ \\
\hline
\end{tabular}

both NADH and NADH dehydrogenase activities was unaffected in complex $\mathrm{I}^{18}$ However, in intact mitochondria with the ND4/11778 mutation, the rates of oxidation of NADH-dependent substrates, not of succinate, were found to be decreased. ${ }^{1821}$ The rates of succinate oxidation were slightly elevated. ${ }^{18}$ That ND4/11778 mutation results in complex I deficiency in functions other than electron transfer between $\mathrm{NADH}$ and ubiquinone was hypothesised. ${ }^{18}$ However, ATP synthesis measured according to the $\mathrm{P} / \mathrm{O}$ ratio in isolated mitochondria from muscles of LHON patients with ND4/11778 mutation was reported to be normal. ${ }^{21}$

In this work, we demonstrated normal activity of complexes I+III (NADH-cytochrome $c$ reductase) but elevated complexes II+III (succinate-cytochrome $c$ reductase) of blood cell mitochondria in LHON patients harbouring homoplasmic 11778 point mutation of mtDNA. These results imply that complex II activity is increased in LHON patients. This result may be explained by the fact that 13 mtDNA encoded polypeptides are involved in respiratory functions of complexes I, III, IV, and $\mathrm{V}$, but polypeptides constituting complex II are entirely nuclearly encoded.

Compensatory nuclear gene expression for mitochondrial protein synthesis was previously observed in patients with ischaemic heart disease $^{28}$ and in those with mitochondrial myopathies. ${ }^{29}$ The elevated activity of complex II in our LHON patients with ND4/11778 mutation in mtDNA may be a nuclear compensatory effect for deficiency of respiratory function. Mitochondria with the same genotype have varied rates of respiration in various nuclear backgrounds ${ }^{30}$; nuclear genes may influence to what extent a certain mtDNA mutation affects the respiratory rate in an organ. Activity of electron transfer of complex I may not be reduced by more than $80 \%$ in cells harbouring the 11778 point mutation, so that the defect would be compensated by enhanced expression of mitochondrial protein genes in nuclear DNA. Most tissues may function virtually normally under this condition. Only those tissues such as optic nerves that depend on maximal activity of complex I or lack sufficient compensatory mechanisms may show a defective respiratory function. In this study, we could not find a correlation between the final level of visual acuity and the enzyme activity measured for complex II+III (Table 1).

Nuclearly encoded factors modifying mtDNA expression may be necessary for phenotypic expression of LHON. The male predominance of LHON may be explained by a nuclear modifying factor or a regulatory gene on the X chromosome. Leber's optic atrophy is linked to a factor on the proximal short arm of the X chromosome near the DXS7 locus, ${ }^{31}$ but no further confirmation of linkage has been made. Other authors refuted the $\mathrm{X}$ linked factor, both by linkage and pedigree modelling. ${ }^{32-36}$

It is important to state that, as data reported in this and all previously published papers were 
obtained from non-optic nerve tissues or cells, these data should be considered as only indirect evaluation of mitochondrial respiratory function of affected tissues of LHON patients. An apparent increase of enzyme activity in blood could have no bearing on the disease process.

Although point mutations of many types in human mtDNA are identified to be associated with LHON, the molecular mechanism of the pathogenesis of this disease remains to be elucidated. Our results showed an elevation of complex II activity in Leber's patients with 11778 point mutation, which may be due to a nuclear compensatory effect for respiratory function defects of the mitochondria.

This work was supported by grants to M-Y Y (No NSC 82 $0115-\mathrm{B}-075-128$ ) and to $\mathrm{Y}-\mathrm{H}$ W (No NSC 83-0412-B-010 031-M02) from the National Science Council, and partly by the Institute of Biomedical Sciences, Academia Sinica, Republic of China.

Y-H W would like to thank the National Science Council for the research award received in the course of this study.

1 Wallace DC, Singh G, Lott MT, Hodge JA, Schurr TG Lezza AMS, et al. Mitochondrial DNA mutation associated with Leber's hereditary optic neuropathy. Science 1988; 242: 1427-30

2 Huoponen K, Vilkki J, Aila P, Nikoskelainen EK, Savontaus ML. A new mtDNA mutation associated with Leber hereditary optic neuropathy. Am $\mathcal{f}$ Hum Genet 1991; 48: 147-53.

3 Johns DR, Berman J. Alternative, simultaneous complex mitochondrial DNA mutations in Leber's hereditary optic
neuropathy. Biochem Biophys Res Commun 1991; 174: neuropathy.

4 Brown MD, Voljavec AS, Lott MT, Torrini A, Yang CC, Wallace DC. Mitochondrial DNA complex I and II mutations associated with Leber's hereditary optic neuropathy. Genetics 1992; 130: 163-73.

5 Howell N, Bindoff LA, McCullough DA, Kubacka I, Poulton J, Mackey D, et al. Leber hereditary optic neuropathy: identification of the same mitochondrial ND1 mutation in six pedigrees. Am f Hum Genet 1991; 49: 939-50.

6 Johns DR, Neufeld MJ. Cytochrome $b$ mutations in Leber hereditary optic neuropathy. Biochem Biophys Res Commun 1991; 181: 1359-64.

7 Johns DR, Neufeld MJ, Park RD. An ND-6 mitochondrial DNA mutation associated with Leber hereditary optic neuropathy. Biochem Biophys Res Commun 1992; 187; 1551-7.

8 Brown MD, Voljavec AS, Lott MT, MacDonald I, Wallace DC. Leber's hereditary optic neuropathy: a model fo mitochondrial neurodegenerative disease. FASEB F 1992; 6: 2791-9.

9 Howell N, Kubacka I, Xu M, McCullough DA. Leber hereditary optic neuropathy: involvement of the mitochondrial ND1 gene and evidence for an intragenic suppressor mutation. Am $\mathfrak{H}$ Hum Genet 1991; 48: 935-42.

10 Mackey DA, Howell N. A variant form of Leber hereditary optic neuropathy characterized by recovery of vision and a multistep mitochondrial genetic etiology. Am f Hum Genet 1992; 51: 1218-26.

11 Johns DR. Mitochondrial ND-1 mutation in Leber hereditary optic neuropathy. Am $\mathcal{F}$ Hum Genet 1992; 50: 872-4.

12 Johns DR, Neufeld MJ. Cytochrome c oxidase mutations in Leber hereditary optic neuropathy. Biochem Biophys Res Commun 1993; 196: 810-5.

13 Howell N, Halvorson B, Burns J, Mc Cullough DA, Poulton J. When dose bilateral optic atrophy become Leber hereditary optic neuropathy? Am $\mathcal{f}$ Hum Genet 1993; 53: 959-63.

14 Anderson S, Bankier AT, Barrel BG, De Bruijn MLJ, Coulson DR, Droin J, et al. Sequence organization of human mitochondrial genomes. Nature 1981; 290: 457-65

15 Hatefi Y. The mitochondrial electron transport chain and oxidative phosphorylation system. Annu Rev Biochem 1985; 54: 1015-69.

16 Hatefi Y. ATP synthesis in mitochondria. Eur $\mathcal{f}$ Biochem 1993; 218: 759-67.

17 Morris MA. Mitochondrial DNA mutations and disease: It's the quantity that counts. Neuro-ophthalmology 1993; 13: 243-51.

18 Majander A, Huoponen K, Savontaus ML, Nikoskelainen EK, Wikstrom M. Electron transfer properties of NADH:ubiquinone reductase in the ND1/3460 and ND4/11778 mutations of the Leber hereditary optic neuropathy (LHON). FEBS Lett 1991; 292: 289-92.

19 Parker WD, Oley CA, Parks JK. A defect in mitochondrial electron-transport activity (NADH-coenzyme $Q$ oxidoreductase) in Leber's hereditary optic neuropathy. N Engl reductase) in Leber's here

20 Cortelli P, Montagna P, Avoni P, Sangiorgi S, Bresolin N, Moggio M, et al. Leber's hereditary optic neuropathy: genetics, biochemical, and phosphorus magnetic resonance spectroscopy study in an Italian family. Neurology 1991; 41: 1211-5.

21 Larsson NG, Andersen O, Holme E, Oldfors A, Wahlstrom J. Leber's hereditary optic neuropathy and complex I deficiency in muscle. Ann Neurol 1991; 30: 701-8.

22 Uemura A, Osame $M$, Nakagawa $M$, Nakahara $K$, Sameshima M, Ohba N. Leber's hereditary optic neuropathy: mitochondrial and biochemical studies on muscle biopsies. Br f Ophthalmol 1987; 71: 531-6.

23 Yen MY, Yen TC, Pang CY, Liu JH, Wei YH. Mitochondrial DNA mutation in Leber's hereditary optic neuropathy. Invest Ophthalmol Vis Sci 1992; 33: 2561-6.

24 Yen TC, Chen YS, King KL, Yeh SH, Wei YH. Liver mitochondrial respiratory functions decline with age. Biochem Biophys Res Commun 1989; 165: 994-1003.

25 Zheng X, Shoffner JM, Voljavec AS, Wallace DC. Evaluation of procedures for assaying oxidative phosphorylation enzyme activities in mitochondrial myopathy muscle biopsies. Biochim Biophys Acta 1990; 1019: 1-10.

26 Hsieh RH, Hou JH, Hsu HS, Wei YH. Age-dependent decline of respiratory functions and increase of DNA deletions in human muscle mitochondria. Biochem Mol Biol Int 1994; 32: 1009-22.

27 Markwell MAK, Haas SZ, Tolbert NE, Bibber LL. Protein determination in membrane and lipoprotein samples: manual and automated procedures. Methods Enzymol 1981; 72: 296-303.

28 Corral-Debrinski M, Stepien G, Shoffner JM, Lott MT Kanter K, Wallace DC. Hypoxemia is associated with mitochondrial DNA damage and gene induction. $f A M A$ 1991; 266: 1812-6.

29 Heddi A, Lestienne P, Wallace DC, Stepien G. Mitochondrial DNA expression in mitochondrial myopathies and coordinated expression of nuclear genes involved in ATP production. $₹$ Biol Chem 1993; 268: involved in

30 King MP, Attardi G. Human cells lacking mtDNA: repopulation with exogenous mitochondria by complementation. Science 1989; 246: 500-3.

31 Vilkki J, Ott J, Savontaus M, Aula P, Nikoskelainen EK Optic atrophy in Leber hereditary optic neuropathy is probably determined by an X-chromosomal gene closely linked to DXS7. Am f Hum Genet 1991; 48: 486-91.

32 Chen JD, Cox I, Denton MJ. Preliminary exclusion of an Xlinked gene in Leber optic atrophy by linkage analysis. Hum Genet 1989; 82: 203-7.

33 Carvalho MRS, Muller B, Rotzer E, Berninger T, Kommerell G, Blankenagel A, et al. Leber's hereditary optic neuropathy and the X-chromosomal susceptibility factor: no linkage to DXS7. Hum Hered 1992; 42: 316-20.

34 Sweeney MG, Davis MB, Lashwood A, Brockington M Toscano A, Harding AE. Evidence against an X-linked locus close to DXS7 determining visual loss susceptibility in British and Italian families with Leber hereditary optic neuropathy. Am f Hum Genet 1992; 51: 741-8.

35 Juvonen V, Vilkki J, Aula P, Nikoskelainen E, Savontaus ML. Reevaluation of the linkage of an optic atrophy susceptibility gene to $\mathrm{X}$-chromosomal markers in Finnish families with Leber hereditary optic neuropathy (LHON) Am f Hum Genet 1993; 53: 289-92.

36 Mackey DA. Blindness in offspring of women blinded by Leber hereditary optic neuropathy. Lancet 1993; 341: 1020-1 